\title{
DERMOSCOPY OF THE MONTH
}

\section{Dermatoscopic Features of Combined nevus - a Case Report}

\author{
Jelena STOJKOVIĆ-FILIPOVIĆ1,2, Branislav TRIFUNOVIĆ ${ }^{3}$, Martina BOSIĆ 4
}

${ }^{1}$ Clinic of Dermatovenereology, Clinical Centre of Serbia, Belgrade, Serbia

${ }^{2}$ Department of Dermatovenereology, School of Medicine, University of Belgrade, Serbia

'University Children's Hospital Belgrade, School of Medicine, University of Belgrade, Serbia

${ }^{4}$ Institute of Pathology, School of Medicine, University of Belgrade, Serbia

Correspondence: Jelena Stojković-Filipović, E-mail: sf.jelena@gmail.com

UDC 616.5-006.81-072.1

\begin{abstract}
Combined nevi $(\mathrm{CN})$, a rare nevus type represent a category of so-called compound tumors. Determined by the presence of two or more different nevus in one biopsy specimen, $\mathrm{CN}$ commonly show variable clinical and dermatoscopic features. Therefore, $\mathrm{CN}$ could be a diagnostic challenge. We present a 7-year-old Caucasian girl with a pigmented lesion on the arm of no specified duration. Clinical examination showed sharply demarcated pigmented papule. Dermatoscopy revealed a nonchaotic lesion with structureless well defined, minimally eccentric blue area, structureless brown area and brown clods in a symmetric fashion, no vessels and no other clues for melanoma. Histopathology showed a compound common melanocytic nevus, blue nevus in the centre of the lesion with no signs of atypia. Up to now, only 25 cases of $\mathrm{CN}$ with dermatoscopic description have been published, withno precise dermatoscopic features established yet. Therefore, studies with larger number of cases are needed for the final conclusions.
\end{abstract}

Key words: Nevus, Pigmented; Nevus, Blue; Dermoscopy; Child; Case Reports

\section{Introduction}

Combined nevi (CN) represent uncommon melanocytic lesions comprised of two or more distinct types of melanocytic nevi (1). Although anymelanocytic nevi could be combined, the most prevalent one is blue nevus associated with common melanocytic nevus
(2). Due to various combinations, $\mathrm{CN}$ can express variable clinical aspects. As such, CN could be a diagnostic challenge and clinical examination could be insufficient for the correct diagnosis.

Dermatoscopy improves the diagnostic accuracy of melanocytic lesions (3), provides
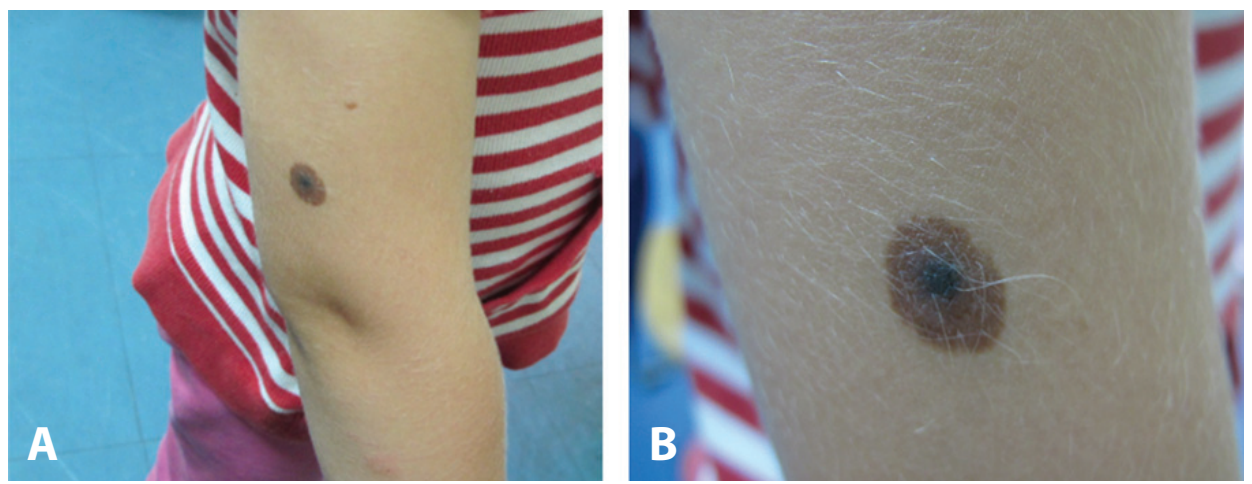

Figure 1. Lesion appearance: A. Pigmented papule on the lateral part of the right arm, B. Close-up of sharply demarcated pigmented papule with a more prominent and pigmented central part. 

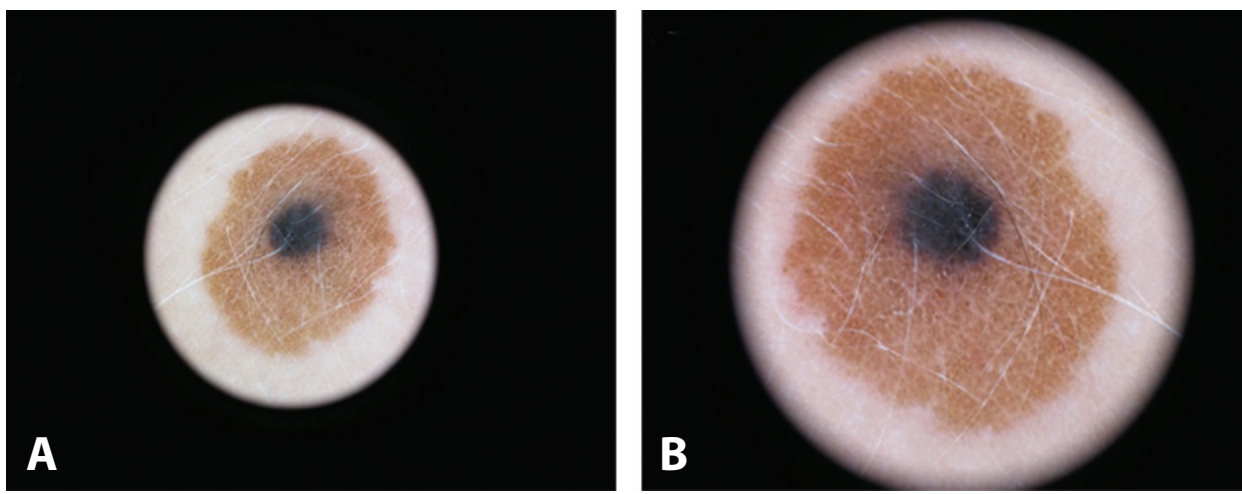

Figure 2. Dermatoscopic features: A. nonchaotic lesion with structureless well defined, minimally eccentric blue area. B. brown structureless, with brown clods in symmetric fashionen circling structureless blue area.

more defining characteristics and increase diagnostic certainty, which can help avoid an unnecessary biopsy. CN represent less than $1 \%$ of all biopsied melanocytic nevi $(4,5)$. Up to now, only 25 cases with dermatoscopic description have been published (6-12), without clearly defined dermatoscopic characteristics of this specific nevi.

\section{Case Report}

A 7-year-old Caucasian girl was referred to the Clinic of Dermatovenerology by the surgeon for the dermatoscopic exam of the lesion on her right arm. The history of the lesion was uncertain, and the parents were not sure when exactly the lesion had appeared. The girl was otherwise healthy, did not have any chronic disease and did not receive any medication. The personal and family history for cutaneous malignancies was negative. Clinical examination showed a sharply demarcated pigmented papule with a more prominent and pigmented central part (Figures 1A, B).

The dermatoscopy examination revealed a nonchaotic lesion with structureless well defined, minimally eccentric blue area. The other part of the lesion was mainly brown structureless, with brown clods in symmetric fashion. Vessels were not noted. The dermatoscopic pattern was unusual, but except the eccentric structureless blue area, there were no other specific clues to melanoma (Figures 2A, B).

The parents were explained that there were no clues to malignancy based on dermatoscopical examination. Since the derma- toscopic pattern was unusual, the control dermatoscopic exam was advised in 3 months. The parents were not motivated for the control exam, and they insisted having the lesion removed. Excision was performed and the histopathology revealed epidermal and dermal nests of common melanocytic nevus in the majority of the lesion, with no signs of atypia or mitotic activity (Figure $3 \mathrm{~A}$ ). In the center of the lesion slender spindle cells and melanophages were found, corresponding to blue nevus (Figures 3B, C). The diagnosis of a combined nevus was made.

\section{Discussion}

Combined nevi are a very rare nevus type $(4,5)$; they present mostly as a variant of blue nevi, acquired (Clark nevi), congenital (Miescher or Unna nevi) and Spitz nevi (4). They are mainly congenital, although not always visible at birth, but later in life (13). Because of the presence of at least two distinct subtypes of nevi, CN exhibit various appearances on both clinical and dermatoscopic assessment. CN often show unspecific, multicomponent, and peculiar patterns. Therefore, $\mathrm{CN}$ can mimic melanomas, their most important differential clinical, dermatoscopical even histopathological diagnosis (4). Larger number of $\mathrm{CN}$ have been evaluated only in a few studies, specifying only their clinical and/or histological features $(2,4,14)$. Up to now, dermatoscopic features of $\mathrm{CN}$ were analyzed only in a small number of cases.

Dermatoscopically, CN appeared as lesions with the simultaneous occurrence of 

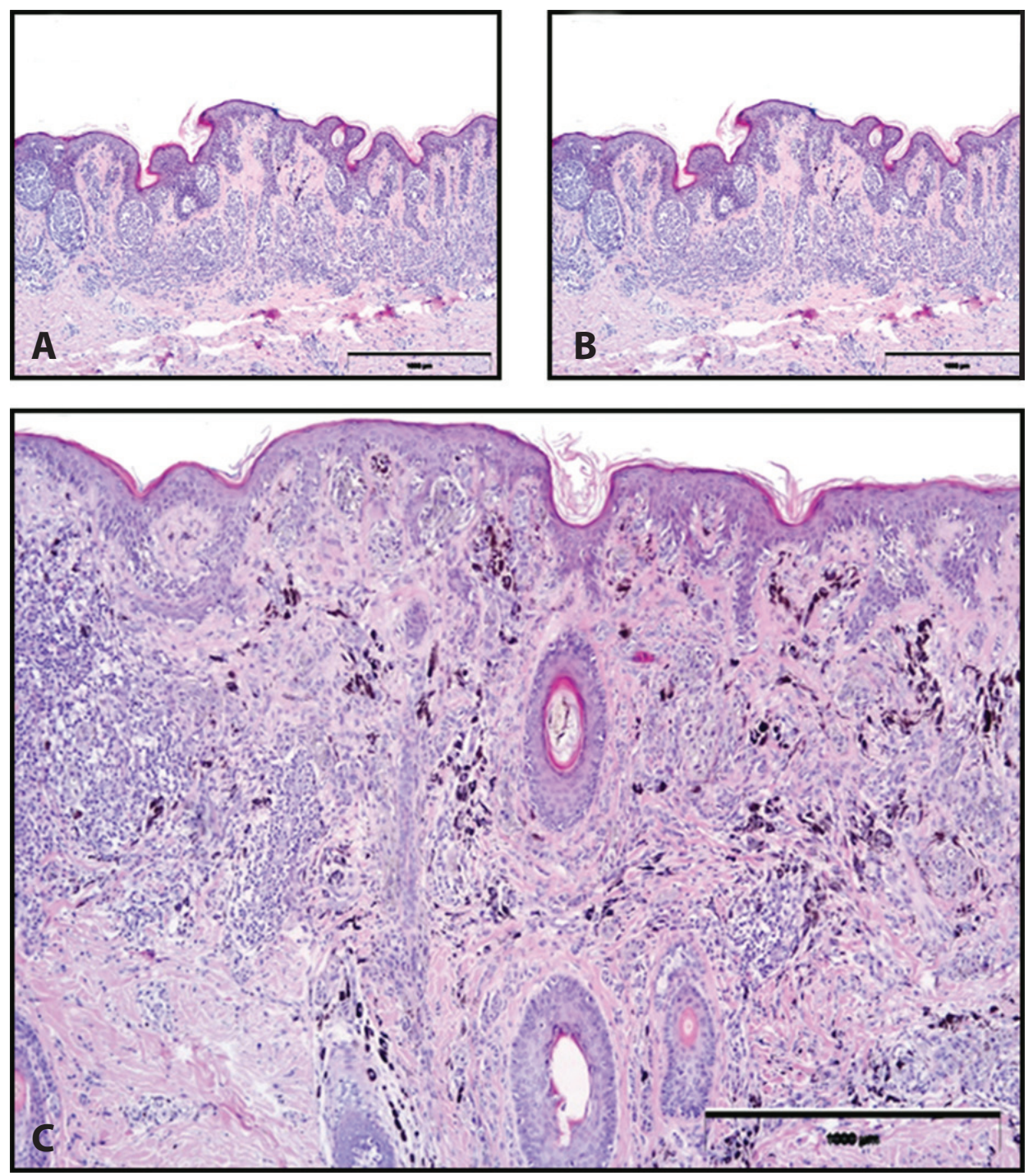

Figure 3. Histopathological findings: A. epidermal and dermal nests of common melanocytic nevus, no signs of atypia or mitotic activity: B, C. Slender spindle cells and melanophages in the center of the lesion.

different colors, primarily blue and brown, which originates from both junctional and dermal portion of the melanocytes (13). Although $\mathrm{CN}$ have multicomponent structure and exhibit at least two patterns, CN commonly show reasonable symmetrical appearance (1). Since chaos (asymmetry of structure or colors) is principally imperative of malignant neoplasm (15), symmetry is one of the most distinguishing features in differentiating $\mathrm{CN}$ from melanomas. Therefore, assessing the lesion for chaos first and, if found, proceeding with search for the clues to malignancy is a very useful algorithm for pigmented skin lesion evaluation $(13,15)$.

Since blue nevus is the most common component of $\mathrm{CN}$, the structureless blue part of the lesion is frequently present and therefore is an important element in the dermatoscopic analysis of CN. Visible structureless blue area is a consequence of histopathological presence of blue nevus (dendritic, cellular blue or deep penetrating nevus) (4) and melanin in the deeper dermal portions. Nevertheless, the presence of ill-defined structureless part of the lesion must always raise suspicion, 
since it is a common characteristic of melanomas with the blue part (15). Another characteristic of structureless blue area in $\mathrm{CN}$ that needs to be assessed in the dermatoscopic analysisis its size and location within the lesion. Although structureless, the blue one can be presented either with eccentric or central distribution, the latter is considered as more typical for benign lesions. Central homogenous or structureless blue area, surrounded by another pattern (globular or reticular) was previously stated as the stereotypical appearance of CN (16). Presence of eccentric structureless blue area, without other clues to malignancy including grey structures, pseudopods-radial lines, white lines, thick reticular lines, ulcerations, and polygons, could be a significant lead to diagnosis of CN. CN with multicomponent pattern and eccentric structureless blue area, lacking specific dermatoscopic features of melanoma do not require further observation. In dermatoscopic assessment of $\mathrm{CN}$, additional clues that have to be assessed for the correct diagnosis are brown dots and clods, blue/gray dots and clods, curved, reticular or branched lines, as well as radial segmental lines and structureless areas of other colours than blue. Structureless brown could be frequently noticed in CN (6). However, it cannot be considered as a dermatoscopic clue for $\mathrm{CN}$ and useful in distinguishing from melanomas with similar aspects, since it could be frequently found in melanomas as well (17). Nevertheless, the presence of structureless white and black ones are another feature specific for melanoma, that directly favours its diagnosis (17).

In dermatoscopic assessment of pigmented lesions, blood vessels morphology is of secondary importance (13). Although blood vessels cannot be used as a clue for pigmented lesions, it could be helpful in further differentiation between $\mathrm{CN}$ and melanomas. The prevalence and arrangement of vessels within the lesion could be important to differentiate between the benign and malignant lesion. In $\mathrm{CN}$ as benign lesions, the vessels, if present, should demonstrate monomorphic arrangement.

Up to now, the exact dermatoscopic criteria of this particular nevus type have not been established and further studies with a greater number of cases are needed for the final conclusions.

\section{Abbreviations \\ $\mathrm{CN}$ - Combined nevi}

\section{References}

1. Barnhill RL. Combined naevus. In: LeBoit PE, Burg G, Weedon D, Sarasin A, editors. World Health Organization classification of tumours. Pathology and genetics. Skin tumours. Lyon: IARC Press; 2006. p. 100-2.

2. Baran JL, Duncan LM. Combined melanocytic nevi: histologic variants and melanoma mimics. Am J Surg Pathol. 2011;35(10):1540-8.

3. Kittler H, Pehamberger H, Wolff K, Binder M. Diagnostic accuracy of dermoscopy. Lancet Oncol. 2002;3(3):159-65.

4. Scolyer RA, Zhuang L, Palmer AA, Thompson JF, McCarthy SW. Combined naevus: a benign lesion frequently misdiagnosed both clinically and pathologically as melanoma. Pathology. 2004;36(5):419-27.

5. Strungs I. Common and uncommon variants of melanocytic naevi. Pathology. 2004;36(5):396-403.

6. de Giorgi V, Massi D, Salvini C, Trez E, Mannone F, Carli P. Dermoscopic features of combined melanocytic nevi. J Cutan Pathol. 2004;31(9):600-4.

7. Dermoscopy of melanocytic neoplasms: combined blue nevi. Arch Dermatol. 2004;140(7):902.

8. Argenziano G. Dermoscopy of melanocytic neoplasms: targetoid combined blue nevi. Arch Dermatol. 2004;140(12):1576.

9. Ferrari A, Lozzi GP, Fargnoli MC, Peris K. Dermoscopic evolution of a congenital combined nevus in childhood. Dermatol Surg. 2005;31(11 Pt 1):1448-50.

10. Piccolo D, Altamura D, Lozzi GP, Peris K. Blue-whitish veil-like structure as the primary dermoscopic feature of combined nevus. Dermatol Surg. 2006; 32(9):1176-8.

11. Panasiti V, Devirgiliis V, Borroni RG, Mancini M, Rossi M, Curzio M, et al. Dermoscopy of a plantar combined blue nevus: a simulator of melanoma. Dermatology. 2007;214(2):174-6.

12. Yaginuma A, Nobeyama Y, Miyake-Nakano S, Ishiji $\mathrm{T}$, Kamide R, Nakagawa $\mathrm{H}$. Case of combined nevus showing a speckled distribution pattern. J Dermatol. 2018;45(8):e232-3.

13. Kittler H, Rosendahl C, Cameron A, Tschandl P. Dermatoscopy. Pattern analysis of pigmented and nonpigmented lesions. 2nd ed. Wien: Facultas; 2016.

14. Pulitzer DR, Martin PC, Cohen AP, Reed RJ. Histologic classification of the combined nevus. Analysis of the variable expression of melanocytic nevi. Am J Surg Pathol. 1991;15(12):1111-22.

15. Weber P, Tschandl P, Sinz C, Kittler H. Dermatoscopy of neoplastic skin lesions: recent advances, updates, and revisions. Curr Treat Options Oncol. 2018;19(11):56. 
16. Zalaudek I, Manzo M, Savarese I, Docimo G, Ferrara $\mathrm{G}$, Argenziano $\mathrm{G}$. The morphologic universe of melanocytic nevi. Semin Cutan Med Surg. 2009; 28(3):149-56.

17. Arevalo A, Altamura D, Avramidis M, Blum A, Menzies $S$. The significance of eccentric and central hyperpigmentation, multifocal hyper/hypopigmentation, and the multicomponent pattern in melanocytic lesions lacking specific dermoscopic features of melanoma. Arch Dermatol. 2008;144(11):1440-4.

\section{Dermatoskopske karakteristike kombinovanog nevusa - prikaz slučaja}

\section{Sažetak}

Kombinovani nevusi, retka grupa nevusa, predstavlja vrstu tzv. složenih tumora. Zbog prisustva dva ili više nevusa u jednom bioptiranom uzorku, kombinovani nevusi uglavnom imaju različite kliničke i dermatoskopske karakteristike, te su često dijagnostički izazov. Predstavljamo sedmogodišnju devojčicu bele puti sa pigmentiranom lezijom, bez preciznog vremena nastanka. Kliničkim pregledom uočena je jasno ograničena pigmentna papula na ruci. Dermatoskopija je pokazala nehaotičnu leziju, sa dobro definisanom, minimalno ekcentričnom plavom zonom bez jasne strukture, smeđom zonom bez jasne strukture i simetrično raspoređenim smeđim globulama, bez krvnih sudova i bez karakteristika melanoma. Histopatološkim pregledom je utvrđen složeni melanocitni nevus, sa plavim nevusom centralno, bez znakova atipije. Do sada je objavljeno 25 slučajeva kombinovanih nevusa sa dermatoskopskim opisom, ali bez jasno utvrđenih dermatoskopskih karakteristika ovog tipa nevusa. Neophodne su studije sa većim brojem slučajeva radi konačnih zaključaka.

Ključne reči: Pigmentni nevus; Plavi nevus; Dermoskopija; Dete; Prikazi slučajeva

Received 24.03.2020.

Accepted 12.04.2020. 